\section{Seattle laboratory arsonist faces prison stretch}

An environmental extremist has been convicted on two counts of arson for her role in a fire at a university laboratory.

On 6 March, a federal jury found Briana Waters guilty of aiding the torching on 21 May 2001 of the University of Washington's Center for Urban Horticulture in Seattle, where activists wrongly believed that trees were being genetically engineered. The jury could not agree on three other counts of conspiracy, possession and use of a destructive device in a crime of violence.

Waters, who acted as lookout, was one of more than a dozen people indicted in 2006 for a series of arsons with environmental motives (see Nature 443, 498; 2006). She faces a minimum of five years in prison.

\section{Giant telescope gets double vision}

The Large Binocular Telescope, situated atop Mount Graham in Arizona, has opened both its eyes.

With two primary mirrors, each of which has a diameter of 8.4 metres, the Large Binocular Telescope is now the world's largest telescope on a single mount. It has a light-collecting area that is equivalent to 11.8 metres. Each mirror can gather light from a different part of the spectrum, or the mirrors can work together to produce sharp images.

The first light pictures gathered by both mirrors, released on 6 March, show a nearby spiral galaxy. The US\$120-million telescope is a joint effort by three Arizona universities; Ohio State University in Columbus; Research Corporation, a private foundation based in Tucson, Arizona; and Italian and German partners. Astronomers are now planning even bigger telescopes (see page 142).

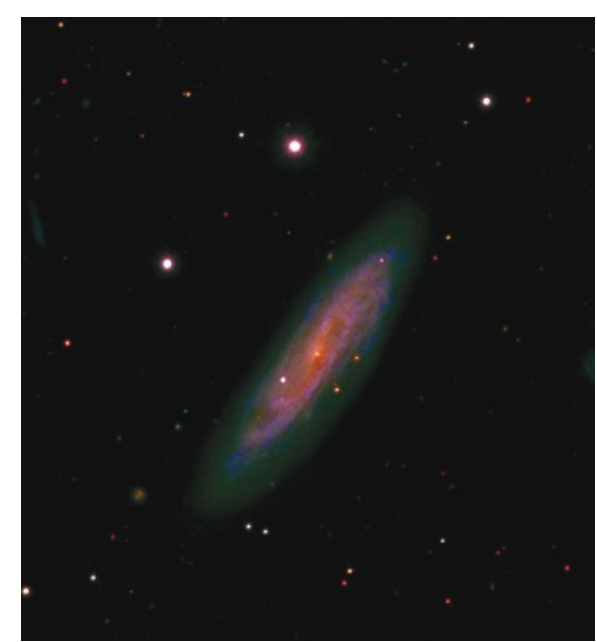

Nearby galaxy NGC 2770, as seen by the Large Binocular Telescope.

\section{Chinese scientists lead panda genome project}

Conservation biologists and geneticists from five countries are planning to sequence the genome of the giant panda.

There are only 1,600 giant pandas in the wild and another 270 in captivity. Loss of habitat, finicky eating habits and disease have taken their toll on the wild population, and breeding efforts have largely failed because of a disinterest in mating. Scientists hope that the sequencing project, announced on 6 March, will yield information that can help both groups.

The genome contains some 3 billion base pairs, and scientists suspect that it holds about the same number of genes as the human genome. The team, led by the Beijing Genomics Institute's Shenzhen branch, hopes to finish a draft within six months.

\section{Officials downplay vaccine's link with autism}

In the wake of a court ruling disclosed last week, US officials have conceded that vaccines may have exacerbated an autismlike disorder in a young girl. The Centers for Disease Control and Prevention (CDC) in Atlanta, Georgia, emphasized that the decision to award damages to the victim's family does not prove a link between autism and vaccines.

The girl has a rare disorder that produces symptoms similar to autism. Her parents argued before a special 'vaccine court' that the disorder surfaced after she received five vaccine shots as an infant. CDC director Julie Gerberding downplayed the link, calling the case "very special".

The ruling was hailed as a victory by activists who believe there is a connection between the vaccines' preservative, thimerosal, and the disorder. About 5,000 other families are also seeking compensation in court.

\section{British government to demand clinical trial data}

The British government is promising to toughen laws to prevent drug companies from withholding data from clinical trials.

Dawn Primarolo, the UK minister of public health, says that both European and British law should be amended to force the timely disclosure of any information relevant to assessing drug risk. She also says that the government will seek clearly defined penalties for non-compliance.

Last week, regulators ended a four-year investigation into the British pharmaceutical firm GlaxoSmithKline without bringing prosecution. The company allegedly failed to provide data related to suicide risk for children taking its anti-depressant drug

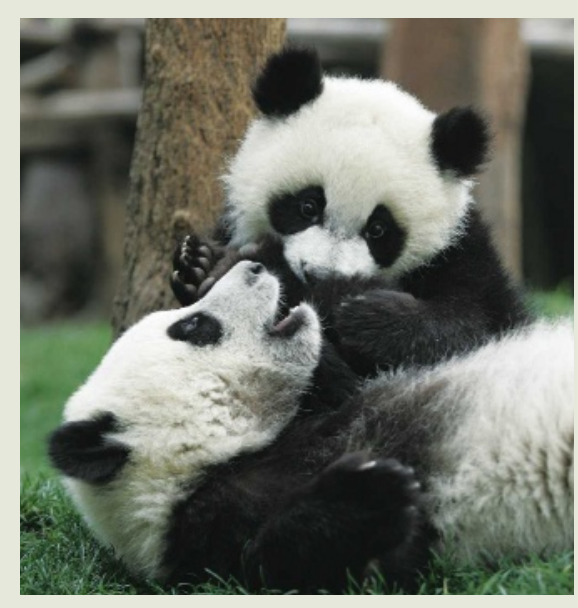

Seroxat (sold in the United States as Paxil). But it did not violate laws in place at the time, investigators say.

\section{Jules Verne sets off for space station}

After years of delay, the European Space Agency has launched what it describes as its most sophisticated spacecraft to date.

An Ariane 5 rocket carried the craft, named Jules Verne, into orbit on 9 March. The spacecraft is the first of a series of Automated Transfer Vehicles (ATVs) that will take supplies to the International Space Station. Unlike current supply vessels, the ATV will dock with the station using lasers rather than being guided by astronauts.

The Jules Verne is scheduled to rendezvous with the station in early April. At least four more ATVs will follow, one every 18 months.

\section{Charity to focus scientists' skills on the needy}

A new charity will direct British scientific talent towards problems in the developing world. Science for Humanity is funded by the London-based National Endowment for Science, Technology and the Arts and the Sloane Robinson Foundation, which supports educational and research charities.

Launched in London on 4 March, the organization is asking researchers to help tackle issues such as sanitation, energy, agriculture and shelter. It will begin by recruiting members from the United Kingdom, but hopes to extend its reach to scientists in other nations.

"We understand that the problems in developing countries are complex," says Susan Greenfield, director of the Royal Institution of Great Britain and one of the agency's founders. "That is challenging. But scientists love a challenge." 